\title{
PENGARUH PENERAPAN GOOD GOVERNMENT GOVERNANCE (GGG) DAN PENERAPAN SISTEM PENGENDALIAN INTERN PEMERINTAH (SPIP) TERHADAP KUALITAS PELAPORAN KEUANGAN (Studi Kasus Pemerintah Daerah Provinsi Di Jawa Barat dan Banten)
}

\author{
1) Dr. Dewi Sarifah Tullah,M.Si., Ak., CA. \\ 2) Erma Apriyanti, M.Akun \\ 3) Nanang Wijaya \\ 1. Dosen Program Studi Akuntansi STIE Pandu Madania \\ 2. Dosen Program Studi Akuntansi STIE Pandu Madania \\ 3. Mahasiswa Program Studi Akuntansi STIE Pandu Madania
}

\begin{abstract}
Abstrak
Bentuk pertanggungjawaban dalam penyelenggaraan Pemerintahan salah satunya adalah upaya konkrit untuk mewujudkan transparansi dan akuntabilitas pengelolaan keuangan pemerintah, baik pemerintah pusat maupun pemerintah daerah dengan menyampaikan laporan pertanggungjawaban berupa laporan keuangan.Penelitian ini bertujuan untuk mengetahui pengaruh penerapan good government governance dan penerapan sistem pengendalian intern pemerintah terhadap kualitas pelaporan keuangan daerah pada Provinsi Jawa Barat dan Banten. Data yang digunakan adalah data primer yang diperoleh melalui keusioner. Metode analisis data yang digunakan adalah regresi linier berganda.Hasil dari penelitian ini Penerapangood government governanceberpengaruh terhadap kualitas pelaporan keuangan, sedangkan Penerapan sistem pengendalian intern pemerintah tidak berpengaruh terhadap kualitas pelaporan keuangan daerah.
\end{abstract}

Kata kunci: Good Government Governance, Sistem Pengendalian Intern Pemerintah, Kualitas Pelaporan Keuangan.

\begin{abstract}
The main function of responsibility of govermential management is how to implement transparancy and accountability of financial management. Local goverment and Central goverment must provide the financial statement as concolidate. This research aim to understand what relation between Good Government governance and internal control system of government and financial statement reporting in West Java and Banten province. Analysis by using data primer that source from questioner. Analysis metodh by using multiple linear regresion . Result of this research descript that good government governance has a strong relation to financial statement quality, as while internal control system of government has a weak relation to financial statement quality.
\end{abstract}

Key words : Good Government Governance, Goverment internal control System, Financial staement quality. 


\section{PENDAHULUAN}

Menurut Peraturan Pemerintah Republik Indonesia Nomor 71 Tahun 2010 menyebutkan bahwa "Laporan keuangan merupakan laporan yang terstruktur mengenai posisi keuangan dan transaksi-transaksi yang dilakukan oleh suatu entitas pelaporan".Pemerintah harus mampu menyajikan laporan keuangan yang mengandung informasi keuangan yang berkualitas. Peraturan Pemerintah Republik Indonesia Nomor 71 Tahun 2010 tentang SAP dijelaskan bahwa laporan keuangan berkualitas itu memenuhi karakteristik relevan, andal, dapat dibandingkan dan dapat dipahami.

Laporan keuangan yang dihasilkan oleh pemerintah daerah akan digunakan oleh beberapa pihak yang berkepentingan sebagai dasar untuk pengambilan keputusan. Oleh karena itu, informasi yang terdapat di dalam Laporan Keuangan Pemerintah Daerah (LKPD) harus bermanfaat dan sesuai dengan kebutuhan para pemakai (Nurillah, 2014). Menurut Mardiasmo (2000), salah satu karakteristik kualitatif agar laporan keuangan berkualitas dan bermanfaat bagi para pemakainya yaitu andal. Informasi memiliki kualitas andal jika bebas dari pengertian yang menyesatkan, kesalahan material, dan dapat diandalkan pemakainya sebagai penyajian yang tulus atau jujur (faithful representation) dari yang seharusnya disajikan. (Standar Akuntansi Pemerintah, 2010).

Dalam UU No 15 Tahun 2004 tentang Pemeriksaan Pengelolaan dan Tanggung Jawab Keuangan Negara disebutkan bahwa Pemeriksaan Keuangan Pemerintah Daerahdilakukan oleh Badan Pemeriksaan Keuangan.Pemeriksaan Keuangan oleh BPK tersebut merupakan pemeriksaan pada Laporan Keuangan (LK) Pemerintah Daerah.Hasil pemeriksaan keuangan oleh BPK berupa pernyataan opini tentang tingkat kewajaran informasi yang disajikan dalam laporan keuangan pemerintah.Opini Pemeriksaan adalah pernyataan profesional sebagai kesimpulan pemeriksaan mengenai tingkat kewajaran informasi (keuangan) yang disajikan dalam laporan keuangan.

Berikut ini adalah hasil pemeriksaan BPK atas LKPD yang disampaikan ke dalam Ikhtisar Hasil Pemeriksaan Semester (IHPS) II tahun 2016.Pada pemeriksaan atas seluruh (542) LKPD Tahun 2015, BPK memberikan opini WTP pada 29 provinsi dan 284 kabupaten/ kota.

\section{Tabel 1}

Opini LKPD dari Tahun 2011 sampai dengan tahun 2015

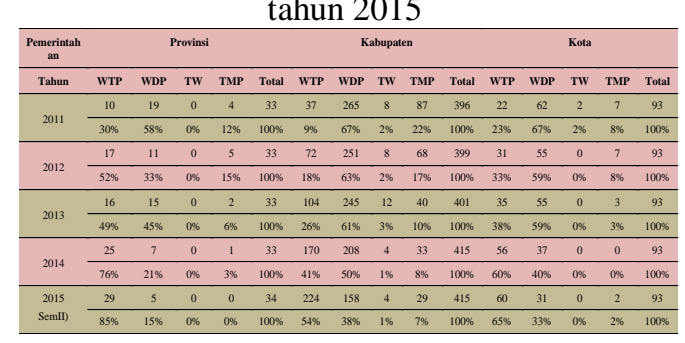

Dari tabel 1 diatas dapat dilihat bahwa opini LKPD telah mengalami peningkatan, namunpeningkatan tersebut masih belum signifikan hal ini dikarenakan masih banyaknya LKPD yang mendapat opini selain WTP sebagai penilaian teratas terhadap LKPD.Peningkatan opini berdasarkan tingkat provinsi dari tahun 2014-2015 terjadi kenaikan sebesar $9 \%$ atau terdapat tambahan tiga provinsi yang mendapat opini WTP. Sedangkan peningkatan opini paling tinggi terjadi pada tahun 2014 yaitu sebesar 27\% dimana terdapat peningkatan opini pada sembilan LKPD tingkat provinsi. Salah satu hal yang mempengaruhi baik buruknya suatu LKPD sehingga tidak tercapainya opini WTP sebagai 
penilaian terhadap kualitas laporan keuangan adalah Good Government Governance (tata kelola pemerintahan yang baik).

Ketua BPK Harry Azhar Azis menyatakan tata kelola pemerintah daerah yang masih rendah menyebabkan pemerintah daerah sulit untuk mendapatkan opini WTP.Opini WTP merupakan refleksi dari rendahnya kualitas laporan keuangan pemerintah daerah.Dalam hal ini berarti, rendahnya kualitas laporan keuangan daerah dapat disebabkan oleh pen-yelengaraan tata kelola yang masih rendah atau buruk.

Good Government Governance merupakan isu yang paling mengemuka dalam pengelolaan administrasi publik saat ini. Pola-pola lama penyelenggaraan pemerintahantidak sesuai lagi dengan tatanan masyarakat saat ini, dimasa lalu negara ataupun pemerintah sangat dominan, menjadi-kan masyarakat menjadi pihak yang sangat diabaikan dalam setiap proses pembangunan. Peranan pemerintah yang dominan tersebut ternyata tidak menjadikan pemerintah mampu menjalankan tugas mulianya untuk mensejahterakan rakyat, yang terjadi adalah pemerintah yang dipilih rakyat mengabaikandan menyalahgunakan kepercayaan rakyat, akibatnya timbul berbagai masalah korupsi yang sulit diberantas(Narang, 2007).Tuntutan masyarakat kepada pemerintah untuk menyelenggarakan pemerintahan yang wajar dan harus direspon oleh pemerintah dengan melakukan perubahan-perubahan yang mengarah pada terwujudnyapenyelenggaraan pemerintahan yang baik.

Tingginya kualitas laporan keuangan pemerintah daerah juga ditentukanoleh seberapa baik pengendalian internal yang dimiliki institusi pemerintah daerah.Pengendalian intern yang lemah menyebabkan

sulitnya

mendeteksiketidakakuratan proses akuntansi sehingga bukti audit yang diperoleh dari data akuntansi menjadi tidak kompeten (Winidyaningrum, 2009).

Bastian (2009) Pengendalian intern rencana organisasi dan semua metode serta ketentuan yang terkoordinasi yang dianut perusahaan untuk melindungi harta miliknya, mengecek kecermatan dan keandalan data akuntansi, meningkatkan efisiensi usaha, dan mendorong ditaatinya kebijakan manajemen yang telah ditetapkan. Unsur-unsur Sistem Pengendalian Intern dalam Peraturan Pemerintah Nomor 60 Tahun 2008 tentang Sistem Pengendalian Intern Pemerintah meliputi lingkungan pengendalian (controlenvironment), penilaian risiko (risk assesment), informasi dan komunikasi (information and communication), aktivitas pengendalian (controlactivities), dan pemantauan (monitoring).

Bentuklaporan pertanggungjawaban atas pengelolaan keuangan daerah selama satu tahun anggaran adalah dalam bentuk LKPD. LKPD harus mengikuti Standar Akuntansi Pemerintahan sesuai Peraturan Pemerintah Nomor 71 tahun 2010 agar lebih accountable dan mempunyai kekuatan hukum dalam upaya meningkatkan kualitas keuangan pemerintah di Indonesia.

\section{Perumusan Masalah}

Sesuai latar belakang masalah yang telah diuraikan diatas, rumusan masalah dalam penelitian ini adalah:

1. Apakah penerapan good
government governance
berpengaruh terhadap kualitas
pelaporan keuangan daerah?
Apakah penerapan sistem
pengendalian intern pemerintah


berpengaruh terhadap kualitas pelaporan keuangan daerah?

\section{Tujuan Penelitian}

Seperti yang telah diuraikan pada latar belakang dan rumusan masalahdiatas maka tujuan penelitian ini adalah:

1. Untuk mengetahui pengaruh penerapan good government governance terhadap kualitas pelaporan keuangan daerah.

2. Untuk mengetahui pengaruh penerapan sistem pengendalian intern pemerintah terhadap kualitas pelaporan keuangan daerah.

\section{PUSTAKA, KONSEPTUAL DAN HIPOTESIS}

\section{GoodGovernmentGovernance}

Tata kelola pemerintahan yang baik (goodgovernmentgovernance) adalah suatu kesepakatan menyangkut pengaturan negara yang diciptakan bersama oleh pemerintah, masyarakat umum, dan swasta. Untuk mewujudkan tata pemerintahan yang baik perlu dibangun dialog antara pelaku-pelaku penting dalam Negara, agar semua pihak merasa memiliki tata pengaturan tersebut. Tanpa kesepakatan yang dilahirkan dari dialog, kesejahteraan tidak akan tercapai karena aspirasi politik maupun ekonomi rakyat pasti terhambat. Terdapat beberapa hal yang perlu diperhatikan oleh pemerintah bahwa masyarakat dapat menilai dan memilih, bahkan meminta jasa layanan yang lebih baik.

\section{Prinsip \\ GoodGovernmentGovernance}

Untuk dapat menerapkan Good Government Governance perlu diperhatikan prinsip-prinsip dasar yang menjadi pedoman dalam penyelenggaraan pemerintahan daerah.Secara umum prinsip-prinsip dasar Good Government Governance menurut International Federation of Accountants (IFAC) terdiri dari tujuh prinsip yaitu integrity, opennes, outcomes, intervention, entity's capacity, managing risk, dan transparency.

\section{Sistem Pengendalian Intern \\ Pemerintah}

Dalam PP No 60 Tahun 2008, Sistem Pengendalian Intern Pemerintah (SPIP) adalah Sistem Pengendalian Intern yang diselenggarakan secara menyeluruh di lingkungan pemerintah pusat dan pemerintah daerah.

Unsur-unsur pengendalian internal menurut COSO (dalam Rosdiani, 2011), meliputi:

1. Lingkungan Pengendalian

Lingkungan pengendalian suatu perusahaan/instansi mencakup seluruh sikap manajemen dan pegawai mengenai pentingnya pengendalian.Pimpinan instansi wajib menciptakan dan memelihara lingkunganpengendalianyang

menimbulkan perilaku positif dan kondusif.Lingkungan pengendalian merupakan landasan untuk semua unsur pengendalian intern, yang membentuk disiplin dan struktur.

2. Penilaian risiko

Dalam rangka penilaian risiko, pimpinan instansi/perusahaan dapat menetapkan tujuannya pada tingkatan kegiatan dengan berpedoman pada peraturan perundang-undangan. Risiko harus diperhitungkan/diidentifikasi dan segera diambil langkah untuk mengendalikannya sehingga tujuan pengendalian internal dapat dicapai. Setelah itu dilakukan analisis untuk memperkirakan besarnya pengaruh dari risiko tersebut serta kemungkinan terjadinya, dan untuk menentukan tindakan yang meminimumkannya. 
3. Kegiatan pengendalian

Pimpinan instansi pemerintah wajib menyelenggarakan kegiatan pengendalian sesuai dengan ukuran, kompleksitas, dari sifat serta tugas dan fungsi yang bersangkutan. Penyelenggaraan kegiatan pengendalian di antaranya dengan melakukan job analysis, yaitu melakukan reviu atas indikator dan ukuran kinerja, otorisasi atas transaksi dan kejadian penting, serta pemisahan fungsi. Selain itu dengan melakukan tindakan tegas terhadap pegawai atas peraturan yang ada agar tidak ada kecurangan dalam pekerjaan.

4. Informasi dan komunikasi

Pimpinan instansi/perusahaan wajib mengidentifikasi, mencatat, dan mengkomunikasikan informasi dalam bentuk dan waktu yang tepat, serta mengikutsertakan pegawai dalam pengambilan kebijakan yang menyangkut aktivitas kinerja pegawai.

5. Pemantauan pengendalian internal

Pemantauan pengendalian internal akan mengidentifikasi di mana letak kelemahannya dan memperbaiki efektifitas pengendalian tersebut.Pemantauan pengendalian dapat dilakukan dengan melakukan evaluasi kualitas, kuantitas, dan kegiatan personalia dalam perusahaan.

\section{Kualitas Laporan Keuangan}

Menurut Bahtiar (2009), tujuan umum dari suatu akuntansi baik dalam bisnis maupun pemerintahan adalah menyediakan informasi keuangan bagi para penggunanya untuk pengambilan keputusan. Didalam kerangka konseptual akuntansi pemerintah, karakteristik kualitatif laporan keuangan meliputi relevansi (relevance), keandalan (reliability), dapat dibandingkan (comparability) dan dapat dipahami (understandability).

\section{Kerangka Konseptual}

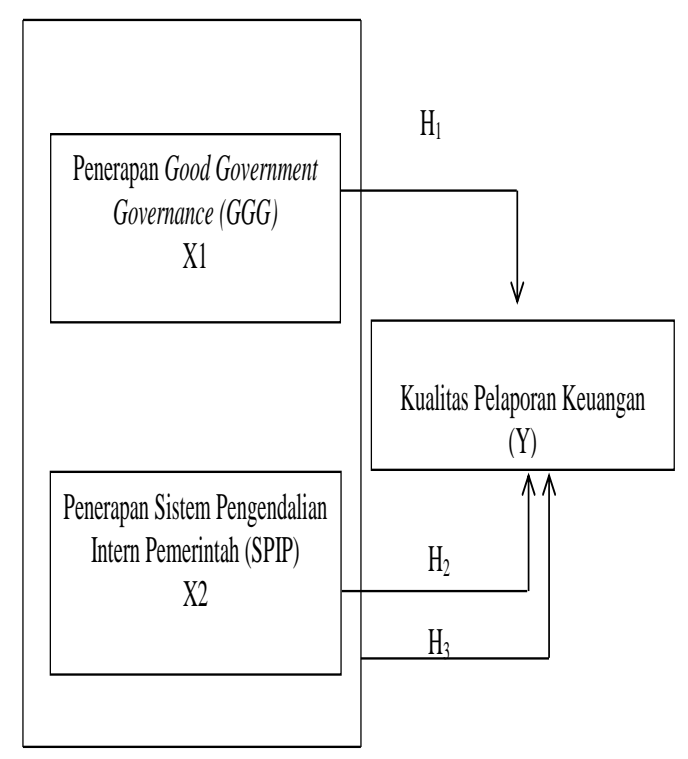

Gambar 1

Kerangka Konseptual Penelitian

\section{Hipotesis}

Menurut Suryadi dan Purwanto (2009) hipotesis merupakan perumusan sementara terhadap rumusan masalah penelitian dan juga dapat mengarahkan penyelidikan selanjutnya melalui pengujian hipotesis. Menurut suryadi dan purwanto (2009), "Pengujian hipotesis adalah prosedur yang didasarkan pada bukti sampel yang dipakai untuk menentukan apakah hipotesis merupakan suatu pernyataan yang wajar dan oleh karenanya tidak ditolak, atau hipotesis tersebut tidak wajar dan oleh karena itu harus ditolak".

Berdasarkan uraian tersebut, maka hipotesis yang dirumuskan adalah sebagai berikut:

$\begin{array}{rlr}\mathrm{H} 1= & \text { Penerapan Good } & \text { Goverment } \\ & \text { Governance berpengaruh terhadap } \\ & \text { kualitas Pelaporan keuangan } \\ & \text { daerah. } & \\ \mathrm{H} 2= & \text { Penerapan Sistem } & \text { Pengendalian } \\ & \text { Intern Pemerintah } & \text { berpengaruh } \\ & \text { terhadap kualitas } & \text { Pelaporan } \\ & \text { keuangan daerah. }\end{array}$




\section{Metode Penelitian}

Metode penelitian yang digunakan dalam penelitian ini meliputi desain penelitian, operasionalisasi variabel, prosedur pengambilan data, dan metode analisis data.

\section{Desain Penelitian}

Penelitian ini memiliki tujuan studi yang bersifat studi kasus (case study), dimana hal pertama yang dilakukan adalah pencarian pustaka yang mendukung secara teoritis, menentukan objek penelitian yang akan diteliti, mencari data-data dari pemerintah daerah wilayah Jawa Barat dan Banten, dengan menggunakan kuesioner untuk mendapatkan data yang diperlukan.

\section{Metode Pengumpulan Data}

Penelitian ini menggunakan data primer, yaitu data yang diperoleh secara langsungdan disebar melalui kuesioner di pemerintah daerah Provinsi Jawa Barat dan Banten.

\section{Teknik Penentuan Sampel}

Pengukuran sampel merupakan suatu langkah yang menentukan besarnya sampel yang diambil dalam melaksanakan suatu penelitian.Sampel dari penelitian ini adalah menggunakan metode sensus, dimana semua anggota populasi dijadikan sebagai sampel.

\section{Operasional variabel}

Agar penelitian ini dapat dilaksanakan sesuai dengan yang diharapkan maka perlu dipahami berbagai unsur-unsur yang menjadi dasar dari suatu penelitian ilmiah yang termuat dalam operasionalisasi variabel penelitian. Operasional variabel merupakan sebuah uraian untuk mengoperasionalisasikan semua variabel, baik variabel bebas (X) maupun variabel terikat
(Y).Operasionalisasi variabel dalam penelitian ini adalah sebagai berikut:

a. Menurut International Federation of Accountants (IFAC) terdiri dari tujuh prinsip yaitu integrity, opennes, outcomes, intervention, entity's capacity, managing risk, dan transparency.GoodGovernment

Governance adalah menyelenggarakan pemerintahan secarasolid dan bertanggungjawab, serta efisien dan efektif, dengan menjaga kesinergisan interaksi yang konstruktif diantara domain-domain negara, sektorswasta dan masyarakat".

b. Sistem Pengendalian Intern Pemerintah (SPIP) terdiri dari unsurunsur sebagai berikut.

1. Lingkungan Pengendalian

2. Penilaian Risiko

3. Kegiatan Pengendalian

4. Informasi dan Komunikasi

5. Pemantauan Pengendalian Intern" (Peraturan Pemerintah Nomor 60 tahun 2008).

c. Dalam kerangka konseptual akuntansi pemerintah, karakteristik kualitatif laporan keuangan meliputi relevansi (relevance), keandalan (reliability), dapat dibandingkan (comparability) dan dapat dipahami (understandability)(Peraturan pemerintah No 71 tahun 2010).

Metode analisis yang digunakan adalah metode analisis kuantitatif.Analisis kuantitatif merupakan suatu analisis yang disajikan dalam bentuk angka-angka yang dipakai sebagai landasan untuk, memperkuat analisis secara kualitatif.Analisis kuantitatif dalam penelitian ini dibagi ke dalam dua kelompok, yaitu pengujian instrumen dan pembuktian hipotesis.

\section{a. Uji Validitas}


Uji validitas digunakan untuk meng-hitung korelasi antara masingmasing pernyataan dengan skor total dengan rumus korelasi product moment.Uji validitas dihitung dengan membandingkan nilai $r$ hitung (correlated item-total correlations) dengan nilai $r$ tabel.Jika $r$ hitung $>$ dari $r$ tabel (pada taraf signifikasi 5\%) maka pertanyaan tersebut dinyatakan valid.Cara melihat tabel ialah dengan melihat baris $\mathrm{N}-2$.

\section{b. Uji reliabilitas}

Uji reliabilitas adalah suatu indeks yang menunjukkan sejauh mana hasil suatu pengukuran dapat dipercaya. Suatu kuesioner dinyatakan reliabel atau handal jika jawaban seseorang terhadap pertanyaan adalah konsisten atau stabil dari waktu ke waktu (Ghozali, 2006).Dalam penelitian ini, uji reliabilitas dilakukan dengan melihat hasil perhitungan nilai cronbach alpha $(\alpha)$. Suatu variabel dikatakan reliabel jika memberikan nilai cronbach alpha $(\alpha)>0,5$ yaitu bila dilakukan penelitian ulang dengan waktu dan dimensi yang berbeda akan menghasilkan kesimpulan yang sama. Tetapi sebaliknya bila alpha $<0,5$ maka dianggap kurang handal, artinya bila variabel-variabel tersebut dilakukan penelitian ulang dengan waktu dan dimensi yang berbeda akan meng-hasilkan kesimpulan yang berbeda.

\section{Pengujian Hipotesis}

\section{Analisis Regresi Linier Berganda}

Regresi berganda digunakan untuk mengetahui pengaruh variabel bebas terhadap variabel tidak bebas atas perubahan dari setiap peningkatan atau penurunan variabel bebas yang akan mempengaruhi variabel terikat. Adapun untuk menganalisis pengaruh penerapan sistem pengendalian intern pemerintah dan good goverment governance terhadap kualitas pelaporan keuangan daerah dengan menggunakan persamaan yang dikutip dari buku Ridwan dan Akdom (2007) yaitu:

$Y=a+b_{1} X_{1}+b_{2} X_{2}+\mathrm{e}$

Keterangan :

$\mathrm{Y}=$ Kualitas pelaporan keuangan pemerintah

$a=$ Nilai constan/reciprocal

$\mathrm{X} 1=$ Good Goverment Governance

$\mathrm{X} 2=$ PenerapanSistem pengendalian

Intern Pemerintah

$\mathrm{e}=$ Standar error

\section{Hasil dan Pembahasan Uji Validitas}

Berdasarkan output SPSS versi 16 dari 46 pernyataan 43dinyatakan valid karena nilai korelasi yang diperoleh masing-masing pernyataan untuk 44 item berada di atas nilai kritis korelasi product moment sedangkan pada 3 pernyataan dinyatakan tidak valid karena berada dibawah nilai kritis. Adapun pernyataan yang dinyatakan tidak valid adalah pernyataan tiga pada indikator relevan, pernyataan satupada indikator lingkungan pengendalian, dan pernyataan tujuh belas pada indikator penilaian risiko.

\section{Hasil Uji Reliabilitas}

Tabel 2

Reliability Statistics

\begin{tabular}{|cc|}
\hline $\begin{array}{c}\text { Cronbach's } \\
\text { Alpha }\end{array}$ & N of Items \\
\hline .706 & 12 \\
.757 & 19 \\
.748 & 18 \\
\hline \multicolumn{2}{|c|}{ Pengujian reliabilitas juga dilaku- }
\end{tabular}

kan secara statistik dengan menghitung besarnya nilai Cronbach's alpha. Hasil seperti yang terlihat pada tabel 2 yang menunjukkan bahwa instrumen dalam penelitian ini realible (handal) karena nilai Cronbach's alpha lebih besar dari 0,7 . 


\section{Hasil Pengujian Hipotesis Analisis Regresi Linier Berganda}

Regresi berganda digunakan untuk mengetahui pengaruh variabel bebas terhadap variabel terikat atas perubahan dari setiap peningkatan atau penurunan variabel bebas yang akan mempengaruhi variabel terikat.

\section{Uji t (Uji Parsial)}

Uji t digunakan untuk menguji dengan parsial masing-masing variabel dengan tingkat signifikan sebesar 0,05. Hasil uji $t$ dapat dilihat pada tabel coefficients pada kolom sig. Jika probabilitas nilai $t$ atau dengan signifikansi $<0,05$. maka dapat dikatakan bahwa terdapat pengaruh antara variabel bebas terhadap variabel terikat secara parsial.

1. Jika nilai signifikan yang diperoleh lebih kecil $<0.05$ dari nilai probabilitas signifikan maka terdapat pengaruh variabel $\mathrm{X}$ terhadap variabel Y.

2. Jika nilai signifikan yang diperoleh lebih besar > 0.05dari nilai probabilitas signifikan maka tidak terdapat pengaruh variabel $\mathrm{X}$ terhadap variabel $\mathrm{Y}$.

Tabel 3

Uji t (Uji Parsial)

\begin{tabular}{clcc}
\hline \multicolumn{2}{c}{$\begin{array}{c}\text { Uji Regresi Linier } \\
\text { Berganda }\end{array}$} & $\boldsymbol{T}$ & Sig. \\
\hline \multirow{3}{*}{1} & (Constant) & 3.545 & .001 \\
& GGG & 4.320 & .000 \\
& SPIP & -1.021 & .315 \\
\hline
\end{tabular}

Dari tabel tersebut diatas nilai signifikan yang diperoleh untuk pengaruh penerapangood government governance terhadap kualitas pelaporan keuangan adalah sebesar $0.000<0.05$ sehingga dapat disimpulkan bahwa $\mathrm{H} 1$ diterima yang berarti terdapat pengaruhgood government governance terhadap kualitas pelaporan keuangan.
Sedangkan nilai signifikan untuk pengaruh penerapan sistem pengendalian intern pemerintah terhadap kualitas pelaporan keuangan sebesar $0.315>0.05$ sehingga dapat disimpulkan bahwa $\mathrm{H} 2$ ditolak yang berarti tidak terdapat pengaruh penerapan sistem pengendalian intern pemerintah terhadap kualitas pelaporan keuangan.

\section{Uji F ( Simultan)}

Uji $\mathrm{F}$ pada dasarnya menunjukkan apakah semua variabel bebas yang dimasukkan dalam model mempunyai pengaruh secara bersama-sama terhadap variabel terikat. Dalam penelitian ini pengujian hipotesis secara simultan dimaksudkan untuk mengukur besarnya pengaruh variabel bebas (good government governance dan penerapaan sistem pengendalian intern) terhadap variabel terikatnya (kualitas laporan keuangan pemerintah).

$\mathrm{F}$ tabel $=\mathrm{f}(\mathrm{k} ; \mathrm{n}-\mathrm{k})=\mathrm{f}(3: 34-3)=3.304$ (dicari menggunakan Aplikasi SPSS 16.0)

Tabel 4

uji F (Simultan)

\begin{tabular}{clcc}
\hline \multicolumn{5}{c}{ Model } & \multicolumn{1}{c}{ Uji F (Simultan) } \\
\hline \multirow{4}{*}{1} & Regression & 9.382 & $.001^{\mathrm{a}}$ \\
& Residual & & \\
& Total & & \\
\hline & Berdasarkan & hasil & pengujian
\end{tabular}

hipotesis (uji F) pada model regresi diatas, didapat nilai signifikansi model regresi secara simultan sebesar 0,001, nilai ini lebih kecil dari signifikan 0,05 $(5 \%)$, yaitu $0,001<0,05$. Maka dapat disimpulkan bahwa secara simultan $\mathrm{H} 3$ diterima, artinya secara bersama-sama atau secara simultan varibel bebas yaitu variabel penerapan good government governance dan penerapan sistem pengendalian intern berpengaruh terhadap variabel terikat yaitu kualitas pelaporan keuangan. 
Analisis Keofisien Determinasi

Tabel 5

Koefisien Determinasi

Model Summary

\begin{tabular}{lllll}
\hline Mo & $R$ & $R$ & Adjust & $\begin{array}{l}\text { Std. } \\
\text { del }\end{array}$ \\
& & Square $R$ & $\begin{array}{l}\text { Error of } \\
\text { Square }\end{array}$ & the
\end{tabular}

\begin{tabular}{lllll} 
& & & Estimate \\
\hline 1 & .614 & .377 & .337 & 4.314 \\
\hline
\end{tabular}

a. Predictors: (Constant), SPIP, $G G G$

Dari hasil output spss tersebut dapat dilihat bahwa nilai koefisien determinasi atau $R$ Square sebesar 0,377 atau $37,7 \%$. Hal ini menunjukan bahwa variabel yang diteliti good government governance dan penerapan sistem pengendalian intern pemerintah memberikan pengaruh terhadap kualitas pelaporan keuangan sebesar $37,7 \%$ sedangkan sisanya $63,3 \%$ dipengaruhi variabel lain yang tidak diteliti.

\section{Pembahasan}

$\begin{array}{llr}\text { Pengaruh } & \text { Good } & \text { Goverment } \\ \text { Governance } & \text { terhadap } & \text { Kualitas } \\ \text { Pelaporan } & \text { Keuangan } & \text { Daerah } \\ \text { Provinsi Jawa } & \text { Barat dan Banten }\end{array}$

Hasil pengujian hipotesis yang pertama pertama menunjukkan bahwa terdapat pengaruh antara good government governance terhadap kualitas pelaporan keuangan pada pemerintah Provinsi Jawa Barat dan Banten.Hal ini sejalan dengan yang diteliti Novita dan Iis Maryani (2014) bahwa terdapat pengaruh good government terhadap kualitas pelaporan keuangan.

$$
\text { Dengan demikian Badan }
$$

Pengelola Keuangan Daerah (BPKD)

Provinsi Jawa Barat dan Banten telah menerapkan prinsip good government governance seperti; 1) Integritas yang terkait dengan budaya kerja, kode etik dalam proses pengadaan barang, serta aturan hukum yang berlaku untuk menghindarkan dari bahaya korupsi, 2) Keterbukaan yang didalamnya berkaitan dengan memberikan informasi keuangankepada masyarakat, public hearing, keterlibatan pihak lain (lembaga swadaya masyarakat, lembaga advokasi kerakyatan, lembaga profesi yang terkait KADIN, HIPMI, akademisi dan para pakar) dalam merencanakan anggaran, 3) Hasil yang terkait dengan evaluasi menggunakan indikator yang jelas dalam mencapai hasil kerja, perhatian terhadap masalah sosial, ekonomi dan lingkungan, 4) Intervensi yang terkait dengan kebijakan yang diambil pemerintah sudah terperinci, pemerintah daerah selalu meminta saran terhadap pihak lain yang terkait dengan masalah keuangan dan pelayanan, 5) Kapasitas entiti yang terkait dengan penyediaan sarana dan prasarana yang selalu up to date, dalam kenaikan jabatan pegawai pemerintahmenggunakan badan pertimbangan jabatan khusus, 6) Manajemen risiko yang terkait dengan pengendalian fisik aset yang dilakukan dengan cara selalu mengidentifikasi, kebijakan dan prosedur pengamanan fisik yang dilakukan secara teratur, dan 7) Akuntabilitas yang telah terlaksana berupa mengumumkan hasil audit setiap tahun dan memberi informasi yang terbuka kepada masyarakat, membuat kebijakan yang tepat dalam membuat laporan keuangan atas proyek fisik dan non fisik yang telah selesai setiap tahunnya.

\section{Pengaruh penerapan Sistem Pengendalian Intern Pemerintah Terhadap Kualitas Pelaporan Keuangan Pemerintah Daerah Provinsi Jawa Barat dan Banten.}

Pada uji parsial untuk variabel sistem pengendalian intern pemerintah (X2) terhadap kualitas pelaporan keuangan daerah (Y) diperoleh nilai 
signifikan yang lebih besar dari nilai probabilitas sehingga dapat disimpulkan bahwa $\mathrm{H} 2$ ditolak yang berarti tidak terdapat pengaruh $\mathrm{X} 2$ terhadap $\mathrm{Y}$. Hal ini disebabkan karena sistem pengendalian intern pemerintah tidak berjalan sebagaimana mestinya, pelaksana lebih cenderung menjalankan tugasnya karena kebiasaan bukan pada prosedur yang sudah ditetapkan.

\section{Kesimpulan}

Kesimpulan yang dapat diambil setelah dilakukan pengujian dan analisis data dalam penelitian ini adalah sebagai berikut:

1. Setelah dilakukan pengujian pada variabel penerapan good govenment governance dapat disimpulkan bahwa penerapan good government governance $\left(\mathrm{X}_{1}\right)$ berpengaruh terhadap kualitas pelaporan keuangan (Y) daerah Provinsi Jawa Barat dan Banten. Jadi semakin baik penerapangood government governance semakin baik pula kualitas pelaporan keuangan.

2. Sedangkan pada variabel penerapan sistem pengendalian intern pemerintah (X2) tidak berpengaruh terhadap kualitas pelaporan keuangan (Y) daerah Provinsi Jawa Barat dan Banten.

\section{Saran}

Berdasarkan kesimpulan yang telah dikemukakan, penulis memberi masukan atau saran mengenai hasil penelitian yang telah dilakukan sebagai berikut:

1. Bagi Badan Pengelola Keuangan Daerah (BPKD) Provinsi Jawa Barat dan Banten, diharapkan lebih meningkatkan lagi prinsip-prinsip good government governance yang agar terciptanya kualitas pelaporan keuangan yang baik pada
Pemerintah Provinsi Jawa Barat dan Banten.

2. Bagi Perangkat Daerah harus lebih meningkatkan lingkungan pengendalian dengan memperhatikan komitmen terhadap kompetensi dan memiliki prosedur yang efektif untuk memantau hasil kewenangan dan tanggung jawab yang didelegasikan. Pemerintah daerah harus meningkatkan informasi dan komunikasi dengan menggunakan berbagai bentuk komunikasi yang sesuai dengan kebutuhannya serta mengelola, mengembangkan, dan memperbaiki sistem informasinya dalam upaya meningkatkan komunikasi secara berkesinambungan.

\section{Daftar Pustaka}

Azlim Darwanis, Usman Abu Bakar, 2012. Pengaruh Penerapan Good Government Governance dan Standar Akuntansi Pemerintahan Terhadap Kualitas Informasi Keuangan. Jurnal Akuntansi

Bastian Indra.2009. Akuntansi Sektor Publik Di Indonesia.BPFE. Yogyakarta

Committee of Sponsoring Organizations of The Treadway Commission (COSO), 2009. Internal ControlIntegrated Fromework, NewYork : AlCPA Publication.

Ghozali, Imam. 2006. Aplikasi Analisis Multivariate dengan Program SPSS. Edisi Kedua. Yogyakarta. Penerbit Universitas Diponegoro.

International Federation of Accountants (IFAC), 2000. Preface to International Public Sector Accounting Standards, New York.

Mardiasmo, 2002.Akuntansi Sektor Publik. , Yogyakarta.

Nurillah (2014). Pengaruh Kompetensi Sumber Daya Manusia, PenerapanSistem Akuntansi 
Keuangan Daerah (SKAD),

Pemanfaatan Tekonologi Informasi

Dan Sistem Pengendalian Intern

Terhadap Kualitas Laporan

Keuangan Pemerintah. (Studi

Empiris Pada SKPD Kota Depok).

Peraturan Pemerintah Nomor 71 Tahun

2010 tentang Standar Akuntansi

Pemerintah.

Purwanto, S.H dan Suryadi.2009.

Statistika Untuk Ekonomi dan

Keuangan Modern. Edisi

Kedua.Jakarta: Salemba Empat

Rosdiani, Committee of Sponsoring

Organizations of The Treadway

Commission (COSO), 2009. Internal

Control-Integrated Fromework,

NewYork : AlCPA Publication.

Teras Narang, 2007. Good Governance

bhb dan Clean Government dalam

Implementasinya di Propinsi

Kalimantan Tengah; Seminar

Pergeseran Paradigma

Kepemerintahan Dari Government ke Governance: Teori dan Praktek.

Komap Fisipol UGM

Winidyaningrum, Celviana. 2009.

Pengaruh Sumber Daya Manusia

Dan PemanfaatanTeknologi

Informasi Terhadap Keterandalan

Dan Ketepatwaktuan Pelaporan

Keuangan Pemerintah Daerah

Dengan Variabel Intervening

Pengendalian Intern Akuntansi

(Studi Empiris Di Pemda

Subosukawonosraten). Program

Studi Magister Akuntansi.

Universitas Sebelas Maret.

Surakarta.

www.BPK.go.id, Badan Pemeriksa

Keuangan (BPK).(2016). Ikhtisar

Hasil Pemeriksaan Semester (IHPS)

II Tahun 2016. 